\title{
ГІПЕРПАРАТИРЕОЗ І НИРКИ
}

\author{
КОЛОМЕЙЧУК Н.О. \\ КНП «Київський міський центр нефрології та діалізу», м. Київ
}

Резюме.

\section{Ключові слова:}

Вступ. Первинний гіперпаратиреоз - це надмірна секреція паратгормону внаслідок дефекту клітин паращитоподібних залоз. Розрізняють декілька клінічних форм: кісткову, ниркову, шлунково-кишкову (виразка шлунка, панкреатит, холецистит), серцево-судинну (артеріальна гіпертонія) та інші. Підвищена секреція паратгормону $є$ причиною посиленого остеолізу та переміщення кальцію у кров, посиленого всмоктування кальцію 3 шлунково-кишкового тракту та підвищеної екскреції кальцію та фосфатів із сечею. У 50\% випадків хвороба протікає безсимптомно і тільки виявлена гіперкальціємія дозволяє запідозрити гіперпаратиреоз.

Мета. Описати клінічні прояви гіперпаратиреозу, проаналізувати динаміку лабораторно-інструментальних показників у пацієнта з високим рівнем паратгормону, диференціювати первинний і вторинний гіперпаратиреоз.

Матеріали і методи. Огляд сучасних та зарубіжних джерел, аналіз та обговорення конкретного клінічного випадку; методики - опис, аналіз, реферування.

Результати. На підставі раптового початку, появи спраги, нудоти, нестримної блювоти, не пов'язаної з прийомом їжі, суглобових та м'язевих болей, спастичних болей в животі, масивної поліорганної кальцифікації, нервово-психічних розладів, підвищеного рівня кальцію, підвищеного рівня паратгормону, остеопорозу, наявності конкрементів в нирках, підвищеного рівня лужної фосфатази, гіповолемії, гіпокаліємії, метаболічного алкалозу, помірної протеїнурії та гематурії, а також, враховуючи наявність провокуючого фактора (психо-емоційний стрес), у пацієнтки діагностовано первинний гіперпаратиреоз, кістково-ниркова форма. Стан після гіперпаратиреоїдного кризу.

Висновок. Суб’єктивні (загальна слабкість, депресія, кістково-суглобовий біль та інші) та об'єктивні (ниркові і кісткові) мають привернути увагу лікаря щодо наявності гіперпаратиреозу. До диференціації первинності чи вторинності гіперпаратиреозу має бути залучений лікар-нефролог.

первинний гіперпаратиреоз, нирки, кістки, діагностика.

Вступ. Первинний гіперпаратиреоз - це надмірна секреція паратгормону внаслідок дефекту клітин паращитоподібних залоз. Розрізняють декілька клінічних форм: кісткову, ниркову, шлунково-кишкову (виразка шлунка, панкреатит, холецистит), серцево-судинну (артеріальна гіпертонія) та інші. Підвищена секреція паратгормону $€$ причиною посиленого остеолізу та переміщення кальцію у кров, посиленого всмоктування кальцію з шлунково-кишкового тракту та підвищеної екскреції кальцію та фосфатів із сечею. У $50 \%$ випадків хвороба протікає безсимптомно і тільки виявлена гіперкальціємія дозволяє запідозрити гіперпаратиреоз.

Мета. Описати клінічні прояви гіперпаратиреозу, проаналізувати динаміку лабораторно-ін- струментальних показників у пацієнта з високим рівнем паратгормону, диференціювати первинний і вторинний гіперпаратиреоз.

Матеріали і методи. Огляд сучасних та зарубіжних джерел, аналіз та обговорення конкретного клінічного випадку; методики - опис, аналіз, реферування.

Клінічний приклад. Хвора С., 54 роки, поступила у відділення загальної хірургії по акту самозвернення о 9 год. 30 хв. 28 жовтня 2006 р. 3 діагнозом «часткова кишкова непрохідність». При надходженні скаржилась на виражену загальну слабкість, постійну нудоту, багаторазову блювоту (до 20 разів на добу), відсутність випорожнень протягом останнього тижня, болі в животі, зменшення маси тіла на 35 кг за останні 3 місяці. Вва- 
жає себе хворою з травня 2006 р., коли почали турбувати головний біль, головокружіння, загальна слабкість, порушення мови.

3 анамнезу. Перебувала 03.05.06 р. 12.05.06 р. в обласній Клінічній Лікарні №1 у нейрохірургічному відділенні з приводу транзиторного порушення мозкового кровообігу за ішемічним типом у вертебробазилярному басейні.

МРT головного мозку від 11.05.06р: ознаки дисциркуляторної енцефалопатії.

Огляд кардіолога: IXC: атеросклеротичний кардіосклероз. Артеріальна гіпертензія. СН-І.

NB! Стан не покращився.

Хвора госпіталізована до Київської центральної басейнової клінічної лікарні міністерства охорони здоров`я України, де перебувала з 29.05.06 р. по 07.06.06 р., де поставлений діагноз: Дисциркуляторна енцефалопатія II ст. Астено-депресивний синдром. Стан після транзиторної ішемічної атаки в ВББ (05.2006р.). Хронічний пієлонефрит, стадія загострення.

NB! Стан не покращився.

Хвора 18.06 .06 р. з діагнозом «Церебральний атеросклероз, дисциркуляторна енцефалопатія III ст., переважно в ВББ. Гіпертонічна енцефалопатія. Поліартрит?» госпіталізована до Головного військового клінічного госпіталю МО України у клініку нейрохірургії та неврології, де перебувала з 26.09.06 р. по 11.10.06 p.

26.09.06 р. стався церебральний судинний криз в ВББ. У день надходження була оглянута спеціалістами, які поставили попередній клінічний діагноз: Церебральний судинний криз в ВББ (26.09.06 р.). Гіпертонічна хвороба III ст. Церебральний атеросклероз, дисциркуляторна енцефалопатія II ст. Виразкова хвороба шлунку, виразка привратнику шлунку, недостатність кардії, рефлюкс-езофагіт. ЖКХ, хронічний калькульозний холецистит, фаза ремісії. CKX. Конкремент лівої нирки. Вторинно-хронічний двобічний пієлонефрит. ХНН І ст. Подагра.

Оглядова рентгенографія органів черевної порожнини: Вільний газ під куполами діафрагми, горизонтальні рівні рідини в петлях кишківника не виявлені.

Езофагогастродуоденоскопія: Різко виражений бульбіт, поверхневий гастрит.

Фіброколоноскопія: Патології не виявлено.

УЗД органів черевної порожнини та нирок: Печінка: не збільшена, підвищенної ехогенності, структура не однорідна, в лівій долі гіпоехогенне утворення 1,5 см. Жовчний міхур: не збільшений, стінки не потовщені, гіперехогенний осад. Підшлункова залоза: не збільшена, підвищенної ехогенності, структура не однорідна. Селезінка: не збільшена, структура однорідна. Права нирка: $11^{*} 6$ см, паренхіма 20мм, ЧМС не розширена, не містить конкременти. Синдром пірамід, що виділяються. Ліва нирка: $11^{\star} 6$ см, паренхіма 20 мм,Ч-
MC розширена, в верхньому сегменті конкремент 1 см, поряд ділянки кальцинозу або коралоподібний камінь.

Стан хворої погіршився: зросли рівні креатиніну і сечовини. Діагноз: Гостра ниркова недостатність, преренального генезу, фаза олігоанурії внаслідок водно-електролітних порушень. Сечокам'яна хвороба. Вторинно-хронічний пієлонефрит, стадія загострення.

Враховуючи:

- Зниження діурезу до 500мл

- Підвищення рівня креатиніну до 392 мкмоль/л

- Підвищення рівня сечовини до19,9 ммоль/л

- Постійну нудоту

- Багаторазове блювання

- Рівень калію 2,8; натрію 134; хлору 84

- Загальний стан важкий, хвора вкрай ослаблена, квола, адинамічна, руховий режим обмежений ліжковим через виражену загальну слабкість і болі в кульшових суглобах

- Шкіра суха, тургор різко знижений

- AT 110/60 мм.рт.ст., Ps 88 за хв.

- Cor тони ритмічні, глухі

- Діурез - 500 мл (зі слів хворої протягом останніх 3-х діб)

- ЦВТ - О мм.вод.ст.

Враховучи вищезазначене, постало питання про Первинний (вторинний?) гіперпаратиреоз, кістково-ниркова форма. Гіперпаратиреоїдний криз.

Рекомендовано:

- Визначення рівня паратгормону

- УЗД щитоподібної залози

- КТ хребта та наднирників (для виключення метастатичного ураження)

- Аналіз сечі на метанефрини

- Рівень кортизолу в добовій сечі, крові

Рівень паратгормону - 1612,632 pg/ml (норма $16-62 \mathrm{pg} / \mathrm{ml}$ )

Добова сеча на метанефрини - 174,26 $\mu \mathrm{g}$ (норма 20-345 $\mu \mathrm{g}$ )

Кортизол добової сечі - 218,0 g ( норма 58,0$403 \mu \mathrm{g})$ 22,6 $\mu \mathrm{g})$

Кортизол крові - 13,98 $\mu \mathrm{g} / \mathrm{dl}$ (норма 6,7-

УЗД щитоподібної залози:

Залоза типової форми та типової локалізації

Збільшена: права доля $56^{\star} 21^{\star} 18,5$ мм ліва доля $54^{\star} 21^{\star} 23 \mathrm{mм}$ перешийок 5,3мм

Контури чіткі, рівні. Капсула ущільнена, не потовщена.

Ехоструктура правої долі однорідна.

Ехоструктура лівої долі не однорідна, декілька ехонегативних утворень по Змм.

KT органів черевної порожнини: Наднирникові залози: правий розмірами, структурою не змінені, лівий збільшений до 23*14 мм. Права нирка: без особливостей. Ліва нирка: локалізація ти- 
пова; деформована, з нечіткими контурами за рахунок округлого утворення жирової щільності, що візуалізується в задній частці та верхньому кінці, розмірами $38^{\star} 33^{\star} 35$ мм. 3 ділянкою підвищеної щільності, розмірами 18*17 мм (звапнення?) та деформує чашково-мискову систему. Аналогічні ділянки менших розмірів в задній стінці капсули утворення. В верхньому кінці округле кістозне утворення, пониженої щільності, розмірами 15*12 мм. Змін структури паранефральної клітковини не визначено. В інтимі аорти та загальних здухвинних артеріях візуалізуються ділянки звапнень.

КT попереково-крижового відділу хребта: КТ-ознаки правобічного сколіозу II-ІІІ ст., остеохондрозу грудного та поперекового відділів хребта.

КТ шийного відділу хребта: КТ-ознаки правобічного сколіозу І-ІІ ст., остеохондрозу шийного відділу хребта.

Рентгенографія органів грудної порожнини: Легеневі поля без вогнищевих та інфільтративних тіней. Серце в межах норми. Діафрагмальні синуси розташовані звичайно.

\section{Консультація психіатра}

Діагноз: Затяжна, ситуаційно-обумовлена невротична депресивна реакція.

\section{Консультація невропатолога}

Діагноз : Дисциркуляторна, атеросклеротична, гіпертонічна енцефалопатія I-II ступеня, переважно судин вертебро-базилярного басейну.

КТ головного мозку: КТ-ознаки ділянок енцефаломаляції в обох гемісферах мозку.

Рентгенографія черепа: Остеопоротична структура кісток склепіння черепу. Нечіткі просвітлення в ділянці тим'яної кістки. Основний синус пневматизований.

Рентгенографія кульшових суглобів, кісток тазу: Виражена зона нерівномірного остеопорозу в зоні шийки лівого стегна.

КТ грудної порожнини: Щитовидна залоза розмірами: права доля 34*19*42,5 мм, ліва доля $36{ }^{\star} 19,3{ }^{\star} 36,8$ мм. Залоза розмірами та структурою не змінена, при в/венному контрастуванні рівномірно накопичує контраст.

КТ-ознаки лімфогенного канцироматозу? Обох легень, правобічного плеврального випоту, збільшених лімфатичних вузлів середостіння.

Консультація онколога:

Діагноз: Дисемінований процес легень, правобічний ексудативний плеврит.

ОМ яєчників (СА-125) - 59,5 U/ml (норма< $<35 \mathrm{U} / \mathrm{ml}$ )

ОМ підшлункової залози (СА-19-9) - 27,6 U/ml (норма $<35 \mathrm{U} / \mathrm{ml}$ )

Консультація гінеколога: Даних за гінекологічну патологію не виявлено.

УЗД органів малого тазу : інволютивні зміни внутрішніх статевих органів.
КT органів малого тазу: Матка в положенні антефлексіо, з гладкими контурами, нормальної конфігурації, розміром $71^{\star} 41^{\star} 45$ мм, розвинута відповідно віку.

Яєчники без особливостей. Сечовий міхур наповнений сечею та контрастом, з гладкими контурами, товщина стінки до 2,5 мм. Пряма кишка, дистальні відділи товстого кішківника розширені. Лімфатичні вузли не візуалізуються. Параректальна клітковина без ознак запалення.

Фібробронхоскопія: Голосові зв'язки не змінені, рухомі. Трахея та бронхи без структурних змін. Каркасність та прохідність не порушені. Слизова оболонка не гіперемована. Без набряку. Судинний малюнок типовий, контактна кровоточивість відсутня. Незначна кількість слизового секрету.

Висновок: Ендоскопічний варіант норми.

Бронхіальний змив на АK, BK - не виявлені.

Цитологічне дослідження бронхіального змиву: поодинокі клітини циліндричного епітелію.

Консультація фтизіатра: Переконливих даних за туберкульозний процес в легенях не отримано.

Рівень паратгормону: 09.11 .06 р. 1612,632 pg/ml, 01.12 .06 р. - 697,784 pg/ml

Сцинтиграфія паращитовидних залоз: При проведенні дослідження з туморотропним РФП, переконливих даних за вогнищеве ураження паращитовидних залоз не спостерігається.

Рівень паратгормону від 14.03.07 р. - 183,599 $\mathrm{pg} / \mathrm{ml}$

Мамографія: В обох молочних залозах явища жирової інволюції з наявністю мілких ліпом до 0,3-0,5см з тонкими звапненими капсулами, переважно в лівій молочній залозі.

Консультація хірурга-ендокринолога: Діагноз: Первинний гіперпаратиреоз, кістково-ниркова форма. Стан після гіперпаратиреоїдного кризу (2006 р). Рекомендовано: оперативне лікування.

Внаслідок проведеного лікування самопочуття значно покращилось, перестала турбувати нудота, припинилась блювота, нормалізувався загальний стан, не турбувала загальна слабкість, нормалізувались показники загального аналізу крові та сечі, знизився рівень креатиніну до 156 мкмоль/л, сечовини до 10,8 ммоль/л, нормалізувався рівень кальцію та інші електролітні та мікроелементні показники, після фази поліурії - добовий діурез стабілізувався на рівні 2,0-2,5 л на добу. Хвора категорично наполягала на виписці додому.

Обговорення. На підставі раптового початку, появи спраги, нудоти, нестримної блювоти, не пов'язаної з прийомом їжі, суглобових та м'язових болей, спастичних болей в животі, масивної поліорганної кальцифікації, нервово-психічних розладів, підвищеного рівня кальцію, підвище- 
ного рівня паратгормону, остеопорозу, наявності конкрементів в нирках, підвищеного рівня лужної фосфатази, гіповолемії, гіпокаліємії, метаболічного алкалозу, помірної протеїнурії та гематурії, а також, враховуючи наявність провокуючого фактора (психо-емоційний стрес), діагностовано первинний гіперпаратиреоз, кістково-ниркова форма. Стан після гіперпаратиреоїдного кризу (2006 р.). Рекомендовано: оперативне лікування.

Серед причин підвищенного рівня паратгормону можуть бути солітарна аденома, множинні аденоми або гіперплазія ПЩЗ, рак ПЩЗ. Рідко ( $\approx 5 \%)$ - спадково детермінований ГПТ як один із складових синдромів множинної ендокринної неоплазії 1 типу (MEN1), 2A типу (MEN2A) або синдрому гіперпаратиреозу, асоційованого з пухлиною верхньої чи нижньої щелепи (HPT-JT), або пов'язаний з інактивуючою мутацією гену, що кодує кальцієвий рецептор (CASR). У нашої пацієнтки слід думати про спадково детермінований ГПТ, який дебютував після стресових подій. Клінічні прояви первинного гіперпаратиреозу характеризуються ураженням центральної нервової системи з наявністю стомлюваності, слабкості, головного білю, депресії, порушенням апетиту, психозів і коматозних станів - все це мало місце і у нашої пацієнтки.

Нефрологи частіше мають справу з вторинним гіперпаратиреозом. Вторинний гіперпаратиреоз $є$ компенсаторною реакцією на тривалу гіпокальціємію, супроводжується підвищеним вмістом неорганічного фосфору (при нирковій формі, синдромі Фанконі) або зниженим (при кишковій формі, синдром мальабсорбції). Клінічно вторинний гіперпаратиреоз проявляється симптомами і ознаками основного захворювання. При гіпокальціємії спостерігаються парестезії різної локалізації з характерними спазмами м'язів кистей і стоп. У проксимальних відділах кінцівок наголошується слабкість м'язів. Зміни кісткової тканини проявляються остеопорозом, остеосклерозом або фіброзно-кістозним оститом. Вторинний гіперпаратиреоз при хронічниму гемодіалізі швидко переходить в третинний гіперпаратиреоз, коли гіперплазія паращитовидних залоз трансформується в аденому, надмірно секретуючи паратгормон. Підвищена секреція ПТГ є причиною посиленого остеолізу та переміщення кальцію у кров, посиленого всмоктування кальцію з шлунково-кишкового тракту та підвищеної екскреції кальцію та фосфатів із сечею.

Таким чином, суб'єктивні симптоми: загальна слабкість, депресія, кістково-суглобовий біль або об'єктивні симптоми ускладнень хронічної гіперкальціємії і симптоми з боку нирок (ниркова коліка, поліурія або симптоми хронічної хвороби нирок); об'єктивні симптоми: кісткові - болі хребта, суглобів і трубчастих кісток кінцівок, патологічні переломи ребер, спричинені загальним чи локальним остеопорозом або вогнищевими дефектами по типу кістозно-фіброзного остеїту, мають привернути увагу лікаря щодо наявності гіперпаратиреозу. До диференціації первинності чи вторинності гіперпаратиреозу має бути залучений лікар-нефролог.

\section{PЕЗЮME}

\section{ГИПЕРПАРАТИРЕОЗ И ПОЧКИ}

Коломейчук Н.А.

КНП «Киевский городской центр нефрологии и диализа», г. Киев

Введение. Первичный гиперпаратиреоз - это избыточная секреция паратгормона вследствие дефекта клеток паращитовидных желез. Различают несколько клинических форм: костную, почечную, желудочно-кишечную (язва желудка, панкреатит, холецистит), сердечно-сосудистую (артериальная гипертония) и другие. Повышенная секреция паратгормона является причиной усиленного остеолиза и перемещения кальция в кровь, усиленного всасывания кальция из желудочно-кишечного тракта и повышенной экскреции кальция и фосфатов с мочой. В $50 \%$ случаев болезнь протекает бессимптомно и только обнаруженная гиперкальциемия позволяет заподозрить гиперпаратиреоз.

Цель. Описать клинические проявления гиперпаратиреоза, проанализировать динамику лабораторно-инструментальных показателей у пациента с высоким уровнем паратгормона, дифференцировать первичный и вторичный гиперпаратиреоз.

Материалы и методы. Обзор современных и зарубежных источников, анализ и обсуждение конкретного клинического случая: методики - описание, анализ, реферирование.

Результаты. На основании субьективных и обьективных симптомов (внезапное начало, появления жажды, тошноты, неукротимой рвоты, не связанной с приемом пищи, суставных и мышечных болей, спастических болей в животе, массивной полиорганной кальцификации, нервно-психических расстройств, повышенного уровня кальция, повышенного уровня паратгормона, остеопороза, наличия конкрементов в почках, повышенного уровня щелочной фосфатазы, гиповолемии, гипокалиемии, метаболического алкалоза, умеренной протеинурии и гематурии), а также, учитывая наличие провоцирующего фактора (психо-эмоциональный стресс), у пациентки диагностирован первичный гиперпаратиреоз, костно-почечная форма. Состояние после гиперпаратиреоидного кризиса.

Вывод. Субъективные (общая слабость, депрессия, костно-суставная боль и другие) и объективные (почечные и костные) симптомы должны привлечь внимание врача думать о наличии гиперпаратиреоза. K дифференциации первичности или вторичности гиперпаратиреоза должен быть привлечен врач-нефролог.

Ключевые слова: первичный гиперпаратиреоз, почки, кости, диагностика. 


\section{SUMMARY}

\section{HYPERPARATHYROESIS AND KIDNEYS}

Kolomeychuk N.

KNP «Kyiv City Center of Nephrology and Dialysis», Kyiv

Introduction. Primary hyperparathyroidism is an excessive secretion of parathyroid hormone due to a defect in the cells of the parathyroid glands. There are several clinical forms: bone, kidney, gastrointestinal (gastric ulcer, pancreatitis, cholecystitis), cardiovascular (hypertension) and others. Increased secretion of parathyroid hormone is the cause of increased osteolysis and movement of calcium into the blood, increased absorption of calcium from the gastrointestinal tract and increased excretion of calcium and phosphate in the urine. In $50 \%$ of cases, the disease is asymptomatic and only detected hypercalcemia suggests hyperparathyroidism.

The purpose. Describe the clinical manifestations of hyperparathyroidism, analyze the dynamics of laboratory and instrumental parameters in a patient with high levels of parathyroid hormone, differentiate between primary and secondary hyperparathyroidism.

Materials and methods. Review of modern and foreign sources, analysis and discussion of a specific clinical case; methods - description, analysis, abstracting.

Results. On the basis of sudden onset, thirst, nausea, uncontrollable vomiting not associated with food intake, joint and muscle pain, spastic abdominal pain, massive multiorgan calcification, neuropsychiatric disorders, elevated calcium levels, elevated levels of parathyroid hormone, osteoporosis, the presence of kidney stones, elevated levels of alkaline phosphatase, hypovolemia, hypokalemia, metabolic alkalosis, moderate proteinuria and hematuria, as well as, given the presence of a provoking factor (psy- cho-emotional stress), the patient was diagnosed with primary hyperparathyroidism. After hyperparathyroid crisis.

Conclusion. Subjective (general weakness, depression, bone and joint pain, etc.) and objective (renal and skeletal) should draw the doctor's attention to the presence of hyperparathyroidism. A nephrologist should be involved in the differentiation of primary or secondary hyperparathyroidism.

Key words: primary hyperparathyroidism, kidneys, bones, diagnosis.

\section{АВТОРСЬКА ДОВІДКА}

Коломейчук Наталія Олександрівна

КНП «Київський міський центр нефрології та діалізу», м. Київ, завідувач відділення моб.: +380973509931

E-mail: tasha 2001@ukr.net

Коломейчук Наталия Александровна

КНП «Киевский городской центр нефрологии и диализа», г. Киев, заведующая отделением

моб.: +380973509931

E-mail: tasha_2001@ukr.net

Kolomeichuk Nataliia

KNE "Kyiv City Center of Nephrology and Dialysis", Kyiv,

head of the department

моб.: +380973509931

E-mail: tasha 2001@ukr.net

Стаття надійшла до редакції 3.11.20 p. 